Review

\title{
Bacterial Bio-Resources for Remediation of Hexachlorocyclohexane
}

\author{
Analía Alvarez ${ }^{1,2, \dagger}$, Claudia S. Benimeli ${ }^{1,3, \dagger}$, Juliana M. Saez ${ }^{1}$, María S. Fuentes ${ }^{1}$, \\ Sergio A. Cuozzo ${ }^{1,2}$, Marta A. Polti ${ }^{1,2}$ and María J. Amoroso ${ }^{1,3,4, *}$
}

1 Pilot Plant of Industrial and Microbiological Processes (PROIMI), CONICET, Av. Belgrano y Pasaje Caseros, 4000 Tucumán, Argentina; E-Mails: alvanalia@gmail.com (A.A.); cbenimeli@yahoo.com.ar (C.S.B.); jsaez@proimi.org.ar (J.M.S.); soledadfs@gmail.com (M.S.F.); sergio.cuozzo@gmail.com (S.A.C.); mpolti@proimi.org.ar (M.A.P.)

2 Natural Sciences College and Miguel Lillo Institute, National University of Tucumán, Miguel Lillo 205, 4000 Tucumán, Argentina

3 North University of Saint Thomas Aquines, 9 de Julio 165, 4000 Tucumán, Argentina

4 Biochemistry, Chemistry and Pharmacy College, National University of Tucumán, Ayacucho 471, 4000 Tucumán, Argentina

$\dagger$ These authors contributed equally to this work.

* Author to whom correspondence should be addressed; E-Mail: amoroso@proimi.org.ar; Tel.: +54-381-4344-888; Fax: +54-381-4344-887.

Received: 6 September 2012; in revised form: 29 September 2012 / Accepted: 17 October 2012 / Published: 15 November 2012

Abstract: In the last few decades, highly toxic organic compounds like the organochlorine
pesticide (OP) hexachlorocyclohexane $(\mathrm{HCH})$ have been released into the environment. All
$\mathrm{HCH}$ isomers are acutely toxic to mammals. Although nowadays its use is restricted or
completely banned in most countries, it continues posing serious environmental and health
concerns. Since HCH toxicity is well known, it is imperative to develop methods to remove
it from the environment. Bioremediation technologies, which use microorganisms and/or
plants to degrade toxic contaminants, have become the focus of interest. Microorganisms
play a significant role in the transformation and degradation of xenobiotic compounds.
Many Gram-negative bacteria have been reported to have metabolic abilities to attack
HCH. For instance, several Sphingomonas strains have been reported to degrade the
pesticide. On the other hand, among Gram-positive microorganisms, actinobacteria have a
great potential for biodegradation of organic and inorganic toxic compounds. This review 
compiles and updates the information available on bacterial removal of $\mathrm{HCH}$, particularly by Streptomyces strains, a prolific genus of actinobacteria. A brief account on the persistence and deleterious effects of these pollutant chemical is also given.

Keywords: organochlorine pesticides; $\gamma$-hexachlorocyclohexane; bioremediation; Streptomyces genus

\section{Introduction}

Highly toxic organic compounds have been synthesized and released into the environment for direct or indirect application over a long period of time. Persistent organic pollutants (POPs) such as pesticides, fuels, polycyclic aromatic hydrocarbons (PAHs), polychlorinated biphenyls (PCBs), chlorophenols and dyes are some of these types of compounds [1]. POPs are extremely resistant to biodegradation by native flora [2] compared to the naturally occurring organic compounds that are readily degraded upon introduction into the environment. Therefore, hazardous wastes and chemicals have become one of the greatest worldwide problems of modern society. Among POPs, organochlorine pesticides (OPs) constitute a major environmental problem, because of their high toxicity, persistence in the environment and ability to bioaccumulate in the food chain [3-5]. These compounds reach aquatic environments through effluent release, atmospheric deposition and runoff among other ways [6]. Because of the low water solubility, OPs have a strong affinity for particulate matter, and consequently, sediments can serve as an ultimate sink $[7,8]$.

The organochlorine compound 1,2,3,4,5,6 hexachlorocyclohexane $(\mathrm{HCH})$ is a broad-spectrum pesticide that was used on a large scale worldwide since the 1940s, and is available in two formulations: technical-grade $\mathrm{HCH}$ (a mixture of different isomers, mainly $\alpha-(60 \%-70 \%), \beta-(5 \%-12 \%)$, $\gamma-(10 \%-15 \%)$ and $\delta-\mathrm{HCH}(6 \%-10 \%))$ and lindane (almost pure $\gamma-\mathrm{HCH})$ (Figure 1). This mixture was marketed as an inexpensive insecticide, but since $\gamma-\mathrm{HCH}$ is the only isomer that exhibits strong insecticidal properties, it has been common to refine it from technical-grade $\mathrm{HCH}$ and market it under the name "lindane". As a result, large quantities of byproducts (mixtures of other HCH isomers) were dumped around production facilities leading to the contamination of many sites worldwide: For each ton of lindane produced, 8-12 tons of wastes are generated (generally enriched in the $\alpha$ and $\beta$ isomers) [9]. Accordingly, there are very few officially recognized OP-contaminated sites in South America, and these are located principally in heavily populated industrial areas, i.e., Sao Paulo (Brazil), Buenos Aires (Argentina), and Santiago and Concepción (Chile). However, these official numbers grossly underestimate the real situation because of the existence of illegally contaminated sites [10]. For instance, the most important known illegal disposal of more than 30 tons of HCHs and other organochlorines such as DDT, took place in the small town of Argentina, in the province of Santiago del Estero [5,10]. 
Figure 1. Structures of hexachlorocyclohexane isomers (adapted from Manickam et al. [11]).

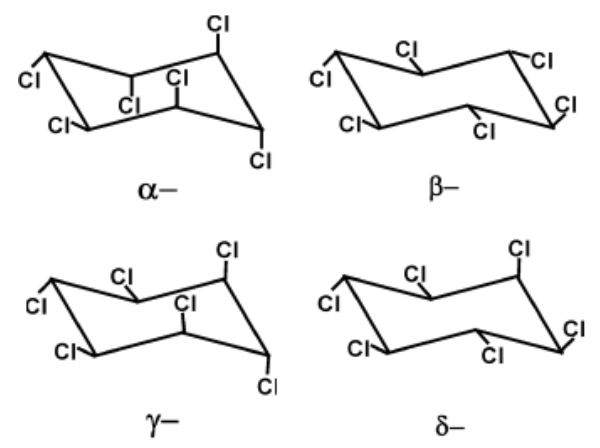

All $\mathrm{HCH}$ isomers are acutely toxic to mammals, due to their mutagenic, teratogenic and carcinogenic properties [12]. Although nowadays its use is restricted or completely banned in most countries, it continues posing serious environmental and health concerns [13]. This is because $\gamma-\mathrm{HCH}$ was widely used as insecticide, which added to its high environmental persistence, ensuring lindane residues would be found all over the world and reaching aquatic environments through effluent release, atmospheric deposition and runoff, among other ways [6,12]. In this context, residues of $\gamma-\mathrm{HCH}$ and others $\mathrm{HCH}$ isomers have now been reported by many countries [13] in samples of air [14,15], water [16,17], soil [17-20], food commodities [21-23], milk [24,25] and even in human blood [26] and adipose tissue [27]. Since HCH spread to remote areas due to migration via various routes, their residues have been detected in Arctic, Antarctic and Pacific Ocean [28], although they had never been used or produced there. The recent inclusion of the $\alpha, \beta$ and $\gamma-\mathrm{HCH}$ isomers in the Stockholm Convention list of POPs has led to a renewed interest in these contaminants and the remediation of affected sites.

Traditional technologies routinely used for remediation of contaminated environmental soil include excavation, transport to specialized landfills, incineration, stabilization and vitrification. However, bioremediation technologies, which imply microorganisms and/or plants to degrade toxic contaminants in soil into less toxic and/or nontoxic substances, have become the focus of interest [29]. Microbial degradation is regarded as an important process of Ops-removal from sediments, and to date, many researchers have studied this issue [2]. In particular, aerobic and anaerobic bacteria are the most active agents of bioremediation [30], having the ability to interact, both chemically and physically, with substances leading to structural changes or complete degradation at the target molecule, playing a significant role in the transformation and degradation of pesticides. Even the most persistent pesticides can be metabolized to some extent by microbial cultures, either by utilization of the compounds as a source of energy or nutrients, or by cometabolism with other substrates supporting microbial growth. This last process is probably the most widespread mechanism for pesticide biodegradation [31]. Complete mineralization of pesticides or their transformation to nontoxic products is desirable, but it is more likely to be carried out by consortia of microorganisms than by single isolates [32-34].

As a way of not altering natural ecosystems, the trend in the last years has been the search and utilization of native bacteria. Many Gram-negative bacteria have been reported to have metabolic abilities to attack lindane. Several bacterial strains (predominantly Sphingomonas strains) capable of degrading $\mathrm{HCH}$ isomers under aerobic conditions have been isolated from contaminated soils [35-38]. On the other hand, among Gram-positive microorganisms, actinobacteria-particularly those belonging to the Streptomyces genus - have a great potential for biodegradation of organic and 
inorganic toxic compounds [39,40]. Benimeli et al. [41-45], Cuozzo et al. [46,47], Fuentes et al. [5,48] and Saez et al. [34] isolated and selected wild-type Streptomyces spp. which were able to tolerate and remove several OPs from culture media and soils.

Regarding eukaryotic cells, fungi have great capacity to degrade xenobiotic. Among them, white-rot fungi have been widely used to degrade several classes of pesticides (including $\gamma$-HCH) due to their ligninolytic potential [49-52]. Likewise, many plants-natural, transgenic, and/or associated to rhizosphere microorganisms - are extraordinarily active in removing or immobilizing pollutants, and particularly $\mathrm{HCH}$ isomers [38,53-55]. However, this article is focused on bacteria, although the $\mathrm{HCH}$-bioremediation capacity of certain plants associated with microorganisms is mentioned.

In this review, it is intended to compile and update the information available on bacterial degradation of $\mathrm{HCH}$. A brief account on the persistence and deleterious effects of these pollutant chemicals is also given.

\section{Physicochemical Properties of Hexachlorocyclohexane: Persistence and Deleterious Effects}

Persistence and mobility of pesticides are defined primarily by their physical and chemical properties [37,56]. Li and Wania [57] compiled selected physicochemical properties, including vapor pressure, water solubility, Henry's law constant $(H)$, octanol-water partition coefficient $\left(K_{\mathrm{OW}}\right)$, and octanol-air partition coefficient (KOA) of major OPs. These properties have been used to screen many chemicals for persistent organic pollutants criteria [58]. For $\mathrm{HCH}$ isomers, such properties are quite different from one to another, depending on the chlorine positions in the cyclohexane ring (Figure 1) [12,37]. For instance, the vapor pressure of $\alpha-\mathrm{HCH}$ is somewhat less than of $\gamma-\mathrm{HCH}$. $\alpha-\mathrm{HCH}$ has also been shown to be slightly more lipophilic than $\gamma-\mathrm{HCH}\left(\log K_{\text {ow }} 3.8\right.$ versus 3.6). The Henry's law constant for $\alpha-\mathrm{HCH}$ is about twice as high as that of $\gamma-\mathrm{HCH}$, so $\alpha-\mathrm{HCH}$ is more likely to partition to the air. Another important difference between the isomers is the persistence of the $\beta$-isomer. $\beta-\mathrm{HCH}$ is more resistant to environmental degradation, it is also more lipophilic than the other isomers. These properties may result from its significantly smaller molecular volume. Since bonds between $\mathrm{H}, \mathrm{C}$, and $\mathrm{Cl}$ in the $\beta-\mathrm{HCH}$ at all six positions are equatorial, the molecule is denser and small enough to be stored in the interstices of lipids in animal tissues.

When comparing $\mathrm{HCH}$ isomers with other $\mathrm{OPs}, \mathrm{HCH}$ exhibit relatively higher water solubility and moderately higher vapor pressures. Therefore, $\mathrm{HCH}$ is usually present in the environment as a gas in the atmosphere or dissolved in water, and a small percentage is adsorbed onto particles [59]. Brubaker and Hites [60] measured the gas phase reaction kinetics of the hydroxyl radical with $\alpha-\mathrm{HCH}$ and $\gamma-\mathrm{HCH}$ and showed that these compounds have fairly long lifetimes in air and therefore can be transported long distances. Despite these approaches, there is controversy in the literature over the persistence of HCHs in soil, water and air, probably due to contrasting data resulting from the complex interactions of environmental factors affecting rates of both abiotic and biotic removal [37].

All the $\mathrm{HCH}$ isomers are acutely toxic to mammals. In addition, chronic exposure has been linked to a range of health effects in humans, including immunosuppression and neurological problems, and has been shown to cause liver cancer in rats and mice [12]; HCHs primarily affect the central nervous system. However, among different isomers, $\alpha-\mathrm{HCH}$ and $\beta-\mathrm{HCH}$ are classified as probable human carcinogen and possible human carcinogen (respectively) by the United States Environmental 
Protection Agency [61]. As the most metabolically stable isomer, $\beta-\mathrm{HCH}$ is the predominant isomer accumulating in human tissues. This tendency to bioaccumulate is a cause of concern as some studies indicate that $\beta-\mathrm{HCH}$ may act as an environmental estrogen [12].

\section{Biodegradation Pathways of Hexachlorocyclohexane}

Different aerobic and anaerobic bacteria have been found to be capable of using halogenated compounds as a growth substrate. Most of the $\mathrm{HCH}$-bioremediating aerobic bacteria and the isolation countries are: Micromonospora sp. and several Streptomyces spp. strains (Argentina) (see Table 1); Bacillus sp. [62] and Pseudomonas sp. [63] (Canada); Sphingobium sp. MI1205 [64] (China); Rhodanobacter lindaniclasticus RP5557 [65,66] and Sphingobium francense sp. [67] (France); Alcaligenes faecalis S-1, Alcaligenes faecalis S-2 [68], Arthrobacter citreus BI-100, Bacillus circulans, Bacillus brevis [69], Microbacterium sp. ITRC1 [56], Pseudomonas aeruginosa [70], Pseudomonas aeruginosa ITRC-5 [71], Pseudomonas sp. [72], Sphingobium chinhatense IP26 [73], Sphingobium indicum B90A [74], Sphingobium quisquiliarum P25 [75], Sphingobium ummariense RL-3 [76], Sphingobium sp. UM2, Sphingobium sp. HDU05, Sphingobium sp. HDIP04, Sphingobium sp. F2, Sphingomonas sp. UM1 [77] and Xanthomonas sp. ICH12 [78] (India); Sphingobium japonicum UT26 [79], Sphingobium sp. BHC-A [80], Sphingobium sp. SS04-1, Sphingobium sp. SS04-2, Sphingobium sp. SS04-3, Sphingobium sp. SS04-4, and Sphingobium sp. SS04-5 [81] (Japan); Sphingomonas sp. DS2, Sphingomonas sp. DS2-2, Sphingomonas sp. DS3-1 [35], Sphingomonas sp. a1-2, Sphingomonas sp. a4-2, Sphingomonas sp. a4-5, Sphingomonas sp. a16-10, Sphingomonas sp. a16-12, Sphingomonas sp. $\gamma 1-7$, Sphingomonas sp. $\gamma 12-7$, Sphingomonas sp. $\gamma 16-1$ and Sphingomonas sp. 16-9 [36] (Spain) and Escherichia coli [82] and Pseudomonas putida [83] (USA).

It is important to note that bioremediation involves the intervention aimed at alleviating pollution, where the organism removes the pollutant by different mechanisms (bioaccumulation, biosorption, biodegradation). This section deals only with bacterial biodegradation of $\mathrm{HCH}$, which tackles the biological bases of the metabolism of recalcitrant compounds [30].

\subsection{Aerobic Hexachlorocyclohexane Degradation in Gram-Negative Microorganisms}

The key reaction during microbial degradation of halogenated compounds is the removal of the halogen atom. During this step, the halogen atoms, which are usually responsible for the toxic and xenobiotic character of the compound is most commonly replaced by hydrogen or a hydroxyl group. Halogen removal reduces both recalcitrance to biodegradation and the risk of forming toxic intermediates during subsequent metabolic steps.

Most of the HCH-degrading aerobes known to date are members of the family Sphingomonadaceae [84,85]. Particularly, the research has focused on strains named Sphingobium japonicum UT26, Sphingobium indicum B90A, and Sphingobium francense Sp+ [35,86].

Genes encoding the $\gamma$-HCH degradation enzymes have been cloned, sequenced and characterized [78]. These genes (called lin genes) were initially identified and characterized for Sphingobium japonicum UT26 [87]. Because plasmids were found to be associated with the horizontal gene transfer of lin genes among the degraders [67], very similar lin genes have also been identified for a 11 the other $\mathrm{HCH}$ degrading sphingomonads tested $[35,67,80,81,84,88]$. Thus, all the degraders isolated from far 
off geographical locations have a nearly identical set of genes [84] In Sphingobium japonicum UT26 [86], the pathway is comprised as follows: linA, encoding a dehydrochlorinase [89]; $\operatorname{lin} B$, encoding a haloalkane dehalogenase [90]; $\operatorname{lin} C$, encoding a dehydrogenase [91]; $\operatorname{lin} D$, encoding a reductive dechlorinase [92]; linE/linEb, encoding a ring cleavage oxygenase [93]; linF, encoding a maleylacetate reductase [93]; lin $G H$, encoding an acyl-CoA transferase [86]; and linJ, encoding a thiolase [86], plus linR/linI, which are regulatory genes [86,94].

There is evidence that LinA dehydrochlorinates $\gamma, \alpha$ and $\delta-\mathrm{HCH}$, while LinB hydrolytically dechlorinates $\beta$ and $\delta-\mathrm{HCH}$ in all strains examined. However, there are strain differences with respect to the hydrolytic dechlorinase-led pathway for $\beta$ - and $\delta$-HCH. For instance, Datta et al. [69] found that $\gamma-\mathrm{HCH}$ aerobic degradation by Arthrobacter citreus BI-100 does not present the formation of tetrachloro-cyclohexadiene $(1,3,4,6-\mathrm{TCDN})$ as a transient product by dehydrochlorination of $\gamma$-pentachloro-cyclohexene $(\gamma-\mathrm{PCCH})$ that occurs during the metabolism of $\gamma-\mathrm{HCH}$ by $S$. japonicum UT26 [91]. It is interesting to note the formation of trichlorocyclohexa-diene (TCCD) by A. citreus BI-100, in contrast to the production of 1,2,4-trichlorobenzene (1,2,4-TCB), as a dead-end product by $S$. japonicum UT26 during the metabolism of $\gamma$-HCH [91]. Furthermore, $S$. japonicum UT26 pathway does not show the appearance of 2-chlorophenol, catechol, and phenol which are present in A. citreus BI-100 $\gamma$-HCH degradation pathway. The study of Datta et al. [69] concludes that some $\gamma-\mathrm{HCH}$ metabolites produced by $A$. citreus BI- 100 are quite different from those produced from $\gamma-\mathrm{HCH}$ by any other single microorganism reported in the literature.

On the other hand, Manickam et al. [78] isolated a Xanthomonas sp. ICH12 strain, capable of biodegrading $\gamma-\mathrm{HCH}$. During the degradation of $\gamma-\mathrm{HCH}$ by Xanthomonas sp. ICH12, the formation of two intermediates, $\gamma$-PCCH and 2,5-dichlorobenzoquinone (2,5-DCBQ), was identified. While $\gamma$-PCCH was reported previously by $S$. japonicum UT26, 2,5-dichlorohydroquinone was a novel metabolite from $\mathrm{HCH}$ degradation.

\subsection{Aerobic Hexachlorocyclohexane Degradation in Gram-Positive Microorganisms}

While there have been many reports regarding aerobic degradation of $\mathrm{HCH}$ by Gram-negative bacteria, little information is available on the ability of biodegradation of $\mathrm{HCH}$ by Gram-positive microorganisms [13]. This preponderance of data on Gram-negative bacteria reflects the fact that molecular techniques for this group of bacteria are much more advanced when compared with Gram-positive bacteria, rather than the intrinsic metabolic potentials of the respective groups. Regarding this approach, the metabolic pathway for pesticide degradation by actinobacterias has not been studied extensively; however, it is known that these microorganisms can produce extracellular enzymes that degrade a wide range of complex organic compounds. A common feature of the aerobic actinobacterias is the presence of many types of monooxygenases and dioxygenases [95].

Manickam et al. [11] isolated the actinobacteria Microbacterium sp. strain ITRC1 that has the ability to degrade all four major isomers of $\mathrm{HCH}$. DNA fragments corresponding to the two initial genes involved in $\gamma$-HCH degradative pathway, encoding enzymes LinB and LinC, were amplified by PCR and sequenced showing that the two genes present in Microbacterium sp. ITRC1 were homologous to those present in S. japonicum UT26. Cuozzo et al. [46] demonstrated for the first time a specific dechlorinase activity in Streptomyces sp. M7 isolated from wastewater sediments of a copper 
filter plant (Table 1). Using $\gamma-\mathrm{HCH}$ as a specific substrate, the authors demonstrated that synthesis of the dechlorinase enzyme was induced by the presence of the pesticide in the culture medium. This enzyme can function at alkaline $\mathrm{pH}$, whereas dechlorinase activity of $S$. japonicum UT26 was optimal in acidic $\mathrm{pH}$ conditions [96]. In addition, the first two metabolites: $\gamma$-PCCH and 1,3,4,6-TCDN, produced by the action of dechlorinase over $\gamma-\mathrm{HCH}$ were detected in the cell-free extract of Streptomyces sp. M7; both metabolites increased after $96 \mathrm{~h}$ of growth. When this strain was cultured in minimal medium with $\gamma-\mathrm{HCH}$, a differential protein band corresponding to polynucleotide phosphorylase appeared in SDS-PAGE. This enzyme plays an important role in the regulation system and could be involved in the regulation of the dechlorinase gene. Andrade and Arraiano [97] found that the polynucleotide phosphorylase in Escherichia coli plays a key role in the regulation of small RNA molecules that control the expression of outer membrane proteins. This enzyme would probably be implied in the regulation of the dechlorinase synthesis in Streptomyces sp. M7. On the other hand, Normand et al. [98] detected a putative 2,5-dichloro-2,5cyclohexadiene-1,4-diol dehydrogenase (2,5-DDOL dehydrogenase) in Frankia, another genus of actinobacteria.

Table 1. $\gamma$-Hexachlorocyclohexane-degrading actinobacteria isolated from Argentina.

\begin{tabular}{|c|c|c|c|}
\hline Actinobacteria strain & Isolation source & $\begin{array}{c}\text { GenBank } \\
\text { access number }\end{array}$ & Action on $\gamma-\mathbf{H C H}$ \\
\hline Micromonospora sp. A10 & ${ }^{a}$ OPs contaminated soil & GQ867054 [5] & ${ }^{\mathrm{c}}$ Grow, remove and degrade $[5,48]$ \\
\hline Streptomyces sp. A1 & OPs contaminated soil & GU085102 [5] & ${ }^{\mathrm{c}}$ Grow, remove and degrade $[5,48]$ \\
\hline Streptomyces sp. A2 & OPs contaminated soil & GU085103 [5] & ${ }^{\mathrm{c}}$ Grow, remove and degrade $[5,48]$ \\
\hline Streptomyces sp. A3 & OPs contaminated soil & GU085104 [5] & ${ }^{\mathrm{c}}$ Grow, remove and degrade $[5,48]$ \\
\hline Streptomyces sp. A5 & OPs contaminated soil & GQ867050 [5] & ${ }^{\mathrm{c}}$ Grow, remove and degrade $[5,48]$ \\
\hline Streptomyces sp. A6 & OPs contaminated soil & GQ867051 [5] & ${ }^{\mathrm{c}}$ Grow, remove and degrade $[5,48]$ \\
\hline Streptomyces sp. A7 & OPs contaminated soil & GQ867052 [5] & ${ }^{\mathrm{c}}$ Grow, remove and degrade $[5,48]$ \\
\hline Streptomyces sp. A8 & OPs contaminated soil & GQ867053 [5] & ${ }^{\mathrm{c}}$ Grow, remove and degrade $[5,48]$ \\
\hline Streptomyces sp. A11 & OPs contaminated soil & GQ867055 [5] & ${ }^{\mathrm{c}}$ Grow, remove and degrade $[5,48]$ \\
\hline Streptomyces sp. A12 & OPs contaminated soil & GQ867056 [5] & ${ }^{\mathrm{c}}$ Grow, remove and degrade $[5,48]$ \\
\hline Streptomyces sp. A13 & OPs contaminated soil & GQ867057 [5] & Grow and remove [5] \\
\hline Streptomyces sp. A14 & OPs contaminated soil & GU085105 [5] & ${ }^{\mathrm{c}}$ Grow, remove and degrade $[5,48]$ \\
\hline Streptomyces sp. C39 & Non-contaminated water & AY741282 [39] & Grow and remove [5] \\
\hline Streptomyces sp. MC1 & Sugar cane & AY741287 [39] & Grow (Unpublished data) \\
\hline Streptomyces sp. M7 & $\begin{array}{c}{ }^{\mathrm{b}} \text { Co-contaminated wastewater } \\
\text { sediment }\end{array}$ & AY459531 [43] & $\begin{array}{c}{ }^{\mathrm{d}} \text { Grow, remove and degrade } \\
{[5,41-46,48,99]}\end{array}$ \\
\hline Streptomyces sp. M15 & $\begin{array}{c}\text { Co-contaminated wastewater } \\
\text { sediment }\end{array}$ & GQ867058 [5] & Grow and remove $[5,41]$ \\
\hline Streptomyces sp. M30 & $\begin{array}{c}\text { Co-contaminated wastewater } \\
\text { sediment }\end{array}$ & GU085106 [5] & Grow and remove [5] \\
\hline Streptomyces sp. M50 & $\begin{array}{c}\text { Co-contaminated wastewater } \\
\text { sediment }\end{array}$ & GQ867059 [5] & ${ }^{\mathrm{c}}$ Grow, remove and degrade [5] \\
\hline
\end{tabular}

${ }^{a}$ Organochlorine pesticides (OPs); ${ }^{b}$ Wastewater sediments contaminated with $\mathrm{Cu}$ and eleven Ops; ${ }^{\mathrm{c}}$ Degradation was determined indirectly by specific dechlorinase activity; ${ }^{\mathrm{d}}$ Degradation was determined by the detection of intermediate metabolites of the catabolic pathway of $\mathrm{HCH}$. 
It is important to note that recently, Isaza et al. [100] identify a haloalkane dehalogenasa (LinB) belonging to Mycobacterium tuberculosis CDC1551. This protein of 300 aminoacids, showed 100\% homology to Mycobacterium tuberculosis KZN 605, Mycobacterium bobis BCG STR Pasteur 117 and 98\% homology to Sphingobiun francensis and Sphingobiun sp. SSD4-1, which would indicate the stability of the gene in Gram-positive as well as in Gram-negative bacteria.

\subsubsection{Indirect Assay to Detect Hexachlorocyclohexane Degradation}

As mentioned above, biodegradation tackles the biological bases of the metabolism of recalcitrant compounds, which deal with the determination of parent chlorinated compounds as well as their intermediate. Chromatography coupled to mass spectrometry has become a significant tool for elucidating pesticide degradation pathways [11,51,78,101-103]. However, this chromatographic technique requires extraction and cleanup of samples, which implies expensive instrumentation.

Another possibility to detect $\mathrm{HCH}$-degrading activities involves a colorimetric assay that detects chloride released from $\mathrm{HCH}$ by dehalogenase enzymes [96]. Since the molecule of $\mathrm{HCH}$ has six chlorine atoms, dechlorination is a very significant step in its degradation process. This technique is sensitive, rapid, inexpensive and highly useful for routine screening of a large number of samples simultaneously [96]. Fuentes et al. [5] used the colorimetric assay to characterize Streptomyces spp. and Micromonospora sp. strains (Table 1) able to dechlorinate $\gamma-\mathrm{HCH}$, chlordane and methoxychlor from the culture medium. Those strains were isolated from soil samples collected from a village named Argentina in the province of Santiago del Estero, (Argentina), where more than 30 tons of obsolete OPs were found in 1994. The authors quantify pesticides removal (by gas chromatography) and indirectly probe its biodegradation by release of chloride ions. Twelve out of 18 studied actinobacteria released chloride to culture medium, and percentages were higher with chlordane as carbon source than with $\gamma-\mathrm{HCH}$ or methoxychlor.

In addition to provide a rapid screening tool for the detection of $\gamma$-HCH-degrading microorganisms, this technique was used also to select microbial consortia for $\gamma-\mathrm{HCH}$ degradation. Mixed cultures are considered to be potential agents in biodegradation of recalcitrant compounds because, in some cases, they have proven to be more efficient than pure cultures [48]. However, selecting the best mixed culture usually implies a large volume of work due to the numerous combinations of pure cultures to be performed to choose the best combination for $\mathrm{HCH}$ degradation. Fuentes et al. [48] measured dechlorinase activity in cell-free extracts of 57 mixed cultures of Streptomyces spp. using this technique. The authors found that the combination of four strains consisting of Streptomyces spp. A2, A5, A11 and M7 (Table 1) presented the lowest value for the ratio between residual $\gamma-\mathrm{HCH}$ and specific dechlorinase activity, and therefore could be a promising consortium for $\gamma-\mathrm{HCH}$ biodegradation.

\section{4. $\gamma$-Hexachlorocyclohexane Removal by Actinobacteria}

Actinobacteria (Gram-positive bacteria with high $\mathrm{G}+\mathrm{C}$ content of DNA) are morphologically complex bacteria that represent an important component of microbial soil biodiversity. Depending on the taxon, they may produce branched rods, complex mycelial structures and spore bodies, motile or nonmotile rods. The group has a great potential for bioremediation of organic and inorganic toxic compounds [104] and particularly pesticide-degrading strains are not restricted to a particular genus or 
family. A review by De Schrijver and De Mot [31] showed that the genera Arthrobacter, Brevibacterium, Clavibacter, Corynebacterium, Mycobacterium, Nocardia, Rhodococus and Micromonospora are pesticide degrading actinobacterias. However, in that study, only one strain belonging to the Streptomyces genus [105] is mentioned as able to dechlorinate $\gamma$-HCH. Most recent studies have isolated and characterized Streptomyces spp. strains able of degrading OPs (including $\gamma-\mathrm{HCH}$ ) and some strains are proposed to be used for soil decontamination (Table 1).

Streptomyces genus is well known for their distinct impacts on mankind since its species are prolific producers of antibiotics [106]. In addition to their potential metabolic diversity, Streptomyces spp. may be well suited for soil inoculation as a consequence of their mycelial growth habit (Figure 2), relatively rapid rates of growth, colonization of semiselective substrates and their ability to be genetically manipulated [107]. For soil bioremediation purposes, one additional advantage is that the vegetative hyphal mass of these microorganisms can differentiate into spores that assist in spreading and persisting. This can be seen as adaptation to living in soil, especially to extreme environmental conditions such as scant nutrients, intense salt load and low $\mathrm{pH}$, as well as contamination [104].

Figure 2. Characteristic vegetative hyphal mass and spores of the Streptomyces genus. (a) Hyphae; (b) Spore forming.

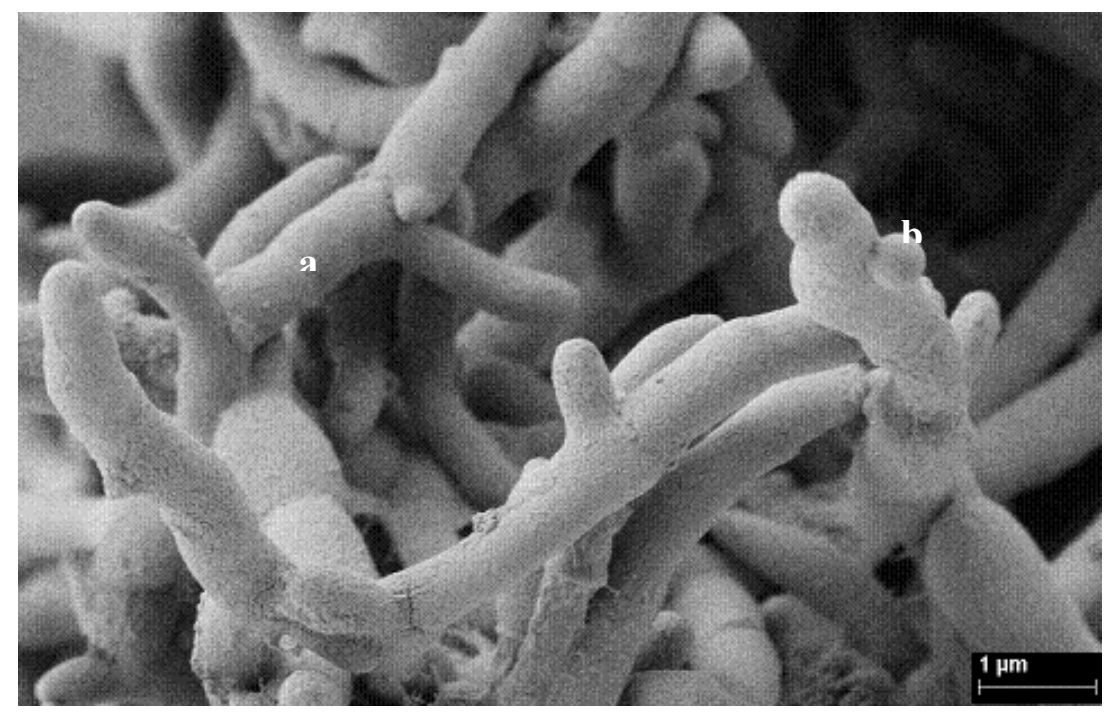

\subsection{Culture Condition for $\gamma$-Hexachlorocyclohexane Removal in Culture Medium}

The fate of organic pollutants in the environment is influenced by environmental factors, such as $\mathrm{pH}$ and temperature, affecting the activity of microorganisms and pesticide removal. Benimeli et al. [41] Benimeli [99] and Fuentes et al. [5] isolated and selected wild type Streptomyces spp. strains which were able to tolerate and remove $\gamma-\mathrm{HCH}$ and other OPs (Table 1). In another work, Benimeli et al. [44] studied the growth of one of these strains named Streptomyces sp. M7 in a poor culture medium (soil extract medium) spiked with $\gamma-\mathrm{HCH}$, at different temperature and $\mathrm{pH}$ values. Despite the poor organic matter, Streptomyces sp. M7 was able to grow for limited time. The authors found that the presence of $\gamma$-HCH did not inhibit microbial growth, since significant differences in bacterial growth with and without the pesticide were not observed. Similar results were obtained previously [43], when Streptomyces sp. M7 was cultured in minimal medium supplemented with $\gamma-\mathrm{HCH} 100 \mu \mathrm{g} \mathrm{L}^{-1}$, 
suggesting that the pesticide could not be toxic for this strain and it would not be either accumulated toxic intermediary metabolites that had an inhibiting effect on the growth. When the effect of the temperature $\left(25^{\circ} \mathrm{C}, 30{ }^{\circ} \mathrm{C}\right.$ and $\left.35{ }^{\circ} \mathrm{C}\right)$ on the growth and pesticide removal of Streptomyces sp. M7 was analyzed, it was observed that $25^{\circ} \mathrm{C}$ was the optimal temperature for microbial growth. On the other the hand, maximum pesticide removal $(70 \%)$ was reached at $30{ }^{\circ} \mathrm{C}$. Similar findings were reported by other authors, although they were working with other microorganisms. For instance, Arisoy and Kolankaya [108] observed that the suitable incubation temperature for maximum growth and degradation activity of $\gamma-\mathrm{HCH}$ by the fungus Pleurotus sajor-caju was $30{ }^{\circ} \mathrm{C}$. Bachmann et al. [109] reported that temperature of $30^{\circ} \mathrm{C}$ was most favorable for the biodegradation of $\gamma-\mathrm{HCH}$ in soil slurry system by the mixed native microbial population of the soil. Manonmani et al. [110] observed the degradation of the $\gamma-\mathrm{HCH}$ by a microbial consortium under a wide range of temperatures $\left(4{ }^{\circ} \mathrm{C}-40{ }^{\circ} \mathrm{C}\right)$ in a liquid culture medium. The optimum for $\gamma-\mathrm{HCH}$ degradation was also $30^{\circ} \mathrm{C}$. Siddique et al. [111] obtained similar results studying the effect of incubation temperature in the biodegradation of $\gamma-\mathrm{HCH}$ by Pandoraea sp.; an incubation temperature of $30{ }^{\circ} \mathrm{C}$ was optimum for degradation of $\gamma$ - $\mathrm{HCH}(57 \%)$ in liquid culture and soil slurry (52\%).

Although evidence indicates that the optimum temperature of $\gamma-\mathrm{HCH}$ removal would be $30{ }^{\circ} \mathrm{C}$, Zheng et al. [112] demonstrated that haloalkane dehalogenases in Sphingobium indicum B90A and Sphingobium japonicum UT26 are very active at temperatures as low as $4{ }^{\circ} \mathrm{C}$. Authors who concluded that Sphingobium strains might be good candidates for developing novel bioremediation techniques for cold regions, where bioremediation is often limited by lower microbial or enzyme activity induced by low temperatures [43], also studied the behavior of Streptomyces sp. M7 cultured with $\gamma$-HCH at different initial $\mathrm{pH}(5,7$ and 9). Pesticide removal $(\sim 4 \%$ and $38 \%)$ was observed at initial $\mathrm{pH}$ of 5 and 9 , respectively. However, the highest removal ability $(\sim 70 \%)$ and maximum growth were reached at an initial $\mathrm{pH}=7$, at 28 days of incubation, which demonstrated that Streptomyces sp. M7 was able to remove $\gamma-\mathrm{HCH}$ over a wide range of $\mathrm{pH}$ in soil extract medium. Other microorganisms may remove $\gamma-\mathrm{HCH}$ at another optimum $\mathrm{pH}$ values. For instance, Arisoy and Kolankaya [108] reported that medium $\mathrm{pH}=5$ was the optimum for both growth and degradation activity of $\gamma$-HCH by the fungus Pleurotus sajor-caju. Manonmani et al. [110] examined the influence of $\mathrm{pH}$ on the degradation of the $\gamma$-HCH isomer in a basal mineral medium by an acclimated consortium of microorganisms. They found that a $\mathrm{pH}$ range of 6-8 was most favorable for growth and degradation of the pesticide. Siddique et al. [111] reported that Pandoreae spp. showed the highest degradation of $\gamma-\mathrm{HCH}$ at an initial $\mathrm{pH}$ of 8 in broth culture.

\subsection{Removal of $\gamma$-Hexachlorocyclohexane in Soil}

Following entry into the soil environment, pollutants rapidly bind to the mineral and organic matter via a combination of physical and chemical processes. Sorption, complexation and precipitation constitute the pollutant-soil interaction. The ability of soils to release pollutants determines its susceptibility to microbial degradation, thereby influencing effectiveness of the bioremediation process [113]. For instance, different soil types can affect redox potential under the same treatment conditions, and these differences in $\mathrm{pH}$ and organic matter might contribute to differences in $\mathrm{HCH}$ removal rates [37]. 
In spite of the complexity of the soil system, research about soil bioremediation are the focus of interest, because this kind of studies usually involve treating the polluted material at the site, resulting in a low-cost, low-maintenance, environmentally friendly and sustainable approach for the cleanup of polluted soils.

In a 70-day study, Rodriguez and Toranzos [114] found that the diversity of the overall bacterial cell number in a tropical soil with a history of $\mathrm{HCH}$ contamination and spiked with $100 \mathrm{mg} \mathrm{kg}^{-1}$ $\gamma-\mathrm{HCH}$ was reduced by $50 \%$ relative to the nonspiked control. Benimeli et al. [45] found opposite results when studying $\gamma-\mathrm{HCH}$ bioremediation ability of Streptomyces sp. M7 growing on sterile soil samples by adding different $\gamma-\mathrm{HCH}$ concentrations. Results showed that significant differences in the growth of Streptomyces sp. M7 in soil were not observed at different pesticide concentrations (100, 150, 200 and $300 \mathrm{mg} \mathrm{kg}^{-1}$ ). These contrasting results are not surprising considering that $\mathrm{HCH}$ may also affect soil microbial populations, stimulating growth of certain microorganisms and exerting toxic effects and inhibiting the growth of others [37].

On the other hand, a significant influence on biodegradation of $\gamma-\mathrm{HCH}$ could be their concentration in the contaminated soils. There is evidence that pesticide biodegradation rates in soil are concentration dependent [37]. Benimeli et al. [45] found that $\gamma-\mathrm{HCH}$ removal by Streptomyces sp. M7 reached approximately $29 \%, 78 \%, 39 \%$ and $14 \%$, at initial $\gamma-\mathrm{HCH}$ concentrations of $100,150,200$ and $300 \mu \mathrm{g} \mathrm{kg}^{-1}$ (respectively) after four-week incubation. Considering that soil contains readily available organic nutrients that microorganisms may prefer for growing, and as Streptomyces sp. M7 growth was continued despite $\gamma-\mathrm{HCH}$ concentration, it would be possible that the pesticide could be used as a secondary substrate source (cometabolism). It is probably the most widespread mechanism for pesticide degradation [31]. This was previously demonstrated by Benimeli et al. [43] in culture medium, where glucose at limited concentration was added.

As mentioned above, the use of microbial mixed cultures increases the number of catabolic pathways available to degrade the contaminants [32]. Regarding this approach, Fuentes et al. [48] studied the role of three mixed cultures consisting of two, three and four Streptomyces spp. strains in decontamination of soil samples polluted with $1.66 \mathrm{mg} \mathrm{kg}^{-1} \gamma-\mathrm{HCH}$. All three consortia exhibited excellent bacterial growth when they were inoculated in $\gamma$-HCH-polluted soil and, interestingly, no growth inhibition was observed. An explanation could be the fact that the original environment where the strains were isolated from was highly polluted with OPs (Table 1). Chromatography analysis demonstrated that the three consortia were able to remove about $32 \%$ of the pesticide after 28 days of incubation.

\section{Hexachlorocyclohexane Removal by Plants Interacting with Microorganisms}

Some phytoremediation techniques, based on the interactions between plants and their associated microorganisms have been proposed as cost-efficient and eco-friendly methods to clean up polluted soils [38,55]. Microbe assisted phytoremediation appears to be particularly effective for organic pollutants, including the more recalcitrant POPs like HCH [115].

Recent studies demonstrate enhanced dissipation and/or mineralization of OPs at the root-soil interface [38]. This rhizosphere effect is generally attributed to an increase in microbial density and/or metabolic activity due to the release of plant root exudates (REs). REs contain water soluble, insoluble, and volatile compounds, including sugars, amino acids, organic acids, nucleotides, flavonoids, phenolic compounds and certain enzymes [116]. Since REs are complex mixtures of substrates, they 
not only provide a nutrient-rich habitat for pollutant degraders but can also potentially enhance biodegradation in different ways: they may facilitate the cometabolic transformation of pollutants with similar structures, induce catabolic enzymes involved in the degradation process and/or enhance the contaminant bioavailability $[38,117]$. In addition, REs may directly induce contaminant degradation by root-driven extracellular enzymes [117,118] as was demonstrated by Magee et al. [119], who reported dechlorination of polychlorinated biphenyls (PCBs) by crude extract of nitrate reductase from Medicago sativa and a pure commercial nitrate reductase from maize. Similar results were obtained by Alvarez et al. [54], who detected specific dechlorinase activity (SDA) in maize REs. In that study, SDA explained $42 \%$ of $\gamma-\mathrm{HCH}$ degradation in minimal medium supplemented with REs and $\gamma-\mathrm{HCH}$.

Phytostimulation of OP-degrading microorganisms is therefore likely to be a successful strategy for the remediation of $\gamma-\mathrm{HCH}$-contaminated environments. However, a careful selection of tolerant plant species and optimizing plant growth are vital since the phytotoxic nature of these contaminants can inhibit plant performance, reducing the overall efficiency of the remediation process [55,120,121]. Some plants are well adapted to acidic conditions as generated during OPs degradation. For instance, Benimeli et al. [45] showed that $\gamma-\mathrm{HCH}$ concentration of 100,200 and $400 \mu \mathrm{g} \mathrm{kg}^{-1}$ soil did not affect the germination and vigor index of maize plants seeded in contaminated nonsterile soils. Additionally, maize plants may create particularly good environmental condition for soil microorganisms [122]. Likewise, the leguminous species Cytisus striatus grow spontaneously on HCH-contaminated sites and has been proposed as a candidate species for the cleanup of this type of contaminant $[38,123]$. Becerra-Castro et al. [55] inoculated substrates seeded with Cytisus striatus with the previously isolated bacteria Rhodococcus erythropolis ET54b and Sphingomonas sp. D4 [55,123]. The authors found that substrates planted with $C$. striatus showed a higher dissipation of $\mathrm{HCH}$ isomers and that both microorganisms protected the plants against the toxic effects of the contaminant. Consequently, they propose that inoculating $C$. striatus with this combination of bacterial strains could therefore be a promising approach for the remediation of $\mathrm{HCH}$-contaminated sites. The presence of plant-colonizing, naphthalene-degrading bacteria were shown to protect their host plants against the toxic effects of naphthalene exposure [116,124]. Likewise, the trichloroethylene (TCE)-degrading poplar endophyte Pseudomonas putida W619-TCE promoted plant growth and reduced TCE phytotoxicity in inoculated poplar cuttings [121].

Alvarez et al. [54] evaluated the effect of maize REs on growth and $\gamma$-HCH removal by Streptomyces sp. A5 and Streptomyces sp. M7 (Table 1). Results showed that both strains were able to grow on minimal medium supplemented with maize REs as sole carbon source, suggesting that these microorganisms are competitive at the rhizosphere level. Furthermore, maize REs markedly influenced the $\gamma-\mathrm{HCH}$ removal by both Streptomyces sp. A5 and M7 since pesticide removal reached approximately 55 and 35\%, respectively, when REs are present in the culture medium. On the contrary, no decrease in pesticide concentration was observed by Renzt et al. [125] and Louvel et al. [126], who studied the repression of phenanthrene-degrading activity of Pseudomonas putida in the presence of REs of different plant species. The authors suggest that as REs are a complex mixture of substrates; some of them could be repressing microbial-degrading activity.

On the other hand, fungi growing in symbiotic association with plants have unique enzymatic pathways that help to degrade pesticides that could not be transformed solely by bacteria [2]. For instance, mycorrhizal fungi form symbioses with a broad range of plant species and can contribute to plant growth 
and survival by reducing stresses associated with toxic wastes. The effects of soil HCH contamination on vegetation and its associated arbuscular mycorrhizas was investigated by Sáinz et al. [127]. The authors found that a preinoculation of four plant species with an isolate of Glomus deserticola obtained from the $\mathrm{HCH}$-contaminated soil resulted in increased growth and fungal colonization of roots, suggesting that the fungus increases the tolerance of plants to the toxic soil environment.

\section{Conclusions}

$\mathrm{HCH}$ is one of the most extensively used OPs for both agriculture and medical purposes. Currently, its use is being phased out because of its toxicity, environmental persistence and accumulation in the food chain. Though the use of technical mixture containing four isomers was banned in several advanced countries, many developing countries continue using $\gamma-\mathrm{HCH}$ (lindane) for economic reasons. Thus, new sites are continuously being contaminated by $\gamma-\mathrm{HCH}$ and the other $\mathrm{HCH}$-isomers. Considerable research on chemical pollutants now provides the necessary body of knowledge to understand their recalcitrance and toxic nature. A possible pathway for remediation of HCH-contaminated soils is the use of indigenous bacteria. There have been many reports regarding aerobic degradation of $\mathrm{HCH}$ by Gram-negative bacteria, especially those belonging to the Sphingomonas genus. The sphingomonads are clearly the group of first choice for further work on strain development for bioremediation purposes, mainly due to the extensive knowledge reached about its metabolic pathways of HCH-degradation. This preponderance of data on Gram-negative bacteria reflects the fact that molecular techniques for this group of bacteria are much more advanced when compared with Gram-positive bacteria, rather than the intrinsic bioremediation potentials of the respective groups. Regarding this approach, Gram-positive bacteria like actinobacteria, are highly promising for HCH-bioremediation purposes. Strains of the Streptomyces genus have been seen to present particularly great potential for remediation of toxic organic and inorganic compounds. In fact, most recent studies have isolated and characterized Streptomyces spp. able to dechlorinate $\gamma-\mathrm{HCH}$ and some strains are proposed to be used for soil decontamination. Furthermore, phytostimulation of $\gamma$-HCH-degrading Streptomyces spp. appear to be a successful strategy for the remediation of $\gamma-\mathrm{HCH}$-contaminated environments.

Work to date indicates that Streptomyces spp. have the requisite capabilities to degrade $\gamma-\mathrm{HCH}$, although further studies on enzymes characterization, particularly for Lin enzymes, are needed to develop effective bioremediation technologies.

\section{Acknowledgments}

This work was supported by Research Council of the National University of Tucuman (CIUNT), National Agency for Science and Technology (ANPCyT), National Council of Scientific and Technical Research (CONICET) and Bunge and Born Foundation. We thank to Lic. Luciana M. Cristobal for technical assistance.

\section{Conflict of Interest}

The authors declare no conflict of interest. 


\section{References}

1. Wania, F.; Mackay, D. Global fractionation and cold condensation of low volatility organochlorine compounds in polar regions. Ambio 1993, 22, 10-18.

2. Diez, M.C. Biological aspects involved in the degradation of organic pollutants. J. Soil Sci. Plant Nut. 2010, 10, 244-267.

3. Ntow, W.J. Pesticide residues in Volta Lake, Ghana, Lakes Reservoirs. Res. Manage. 2005, 10, 243-248.

4. Xue, N.; Zhang, D.; Xu, X. Organochlorinated pesticide multiresidues in surface sediments from Beijing Guanting reservoir. Water Res. 2006, 40, 183-194.

5. Fuentes, M.S.; Benimeli, C.S.; Cuozzo, S.A.; Amoroso, M.J. Isolation of pesticide-degrading actinomycetes from a contaminated site: Bacterial growth, removal and dechlorination of organochlorine pesticides. Int. Biodeterior. Biodegrad. 2010, 64, 434-441.

6. Yang, R.; Ji, G.; Zhoe, Q.; Yaun, C.; Shi, J. Occurrence and distribution of organochlorine pesticides (HCH and DDT) in sediments collected from East China Sea. Environ. Int. 2005, 31, 799-804.

7. Fatoki, O.S.; Awofolu, R.O. Methods for selective determination of persistent organochlorine pesticide residues in water and sediments by capillary gas chromatography and electron-capture detection. J. Chromatogr. 2003, A983, 225-236.

8. Pazou, E.Y.; Boko, M.; van Gestel, C.A.; Ahissou, H.; Lalèyè, P.; Akpona, S.; van Hattum, B.; Swart, K.; van Straalen, N.I. Organochlorine and organophosphorous pesticide residues in the Quémé river catchment in the Republic of Bénin. Environ. Int. 2006, 32, 616-623.

9. Vijgen, J.; Abhilash, P.C.; Li, Y.F.; Lal, R.; Forter, M.; Torres, J.; Singh, N.; Yunus ,M.; Tian, C.; Schäffer, A.; et al. $\mathrm{HCH}$ as new Stockholm Convention POPs, a global perspective on the management of lindane and its waste isomers. Env. Sci. Pollut. Res. 2011, 18, 152-162.

10. Barra, R.; Colombo, J.C.; Eguren, G.; Gamboa, N.; Jardim, W.F.; Mendoza, G. Persistent Organic Pollutants (POPs) in Eastern and Western South American Countries. Rev. Environ. Contam. Toxicol. 2006, 185, 1-33.

11. Manickam, N.; Mau, M.; Schlömann, M. Characterization of the novel HCH-degrading strain, Microbacterium sp. ITRC1. Appl. Microbiol. Biotechnol. 2006, 69, 580-588.

12. Willet, K.L.; Ulrich, E.M.; Hites, R.A. Differential toxicity and environmental fates of hexachlorocyclohexane isomers. Environ. Sci. Technol. 1998, 32, 2197-2207.

13. Lal, R.; Pandey, G.; Sharma, P.; Kumari, K.; Malhotra, S.; Pandey, R.; Raina, V.; Hans, P.E.; Kohler, C.H.; Jackson, C.; et al. Biochemistry of microbial degradation of hexachlorocyclohexane and prospects for bioremediation. Microbiol. Mol. Biol. Rev. 2010, 74, 58-80.

14. Li, J.; Zhu, T.; Wang, F.; Qiu, X.H.; Lin, W.L. Observation of organochlorine pesticides in the air of the Mt. Everest region. Ecotoxicol. Environ. Saf. 2006, 63, 33-41.

15. Popp, P.; Bruggemann, L.; Keil, P.; Thuss, U.; Weiss, H. Chloro-benzenes and hexachlorocyclohexanes (HCHs) in the atmosphere of Bitterfeld and Leipzig (In Germany). Chemosphere 2000, 41, 849-855.

16. Bakore, N.; John, P.J.; Bhatnagar, P. Organochlorine pesticide residues in wheat and drinking water samples from Jaipur, Rajasthan, India. Environ. Monit. Assess. 2004, 98, 381-389. 
17. Kumari, B.; Madan, V.K.; Kathpal, T.S. Status of insecticide contamination of soil and water in Haryana, India. Environ. Monit. Assess. 2007, 136, 239-244.

18. Concha-Graña, E.; Turnes-Carou, M.I.; Muniategui-Lorenzo, S.; López-Mahia, P.; Prada-Rodriguez, D.; Fernández-Fernández, E. Evaluation of HCH isomers and metabolites in soils, leachates, river water and sediments of a highly contaminated area. Chemosphere 2006, 64, $588-595$.

19. Gong, Z.M.; Xu, F.L.; Dawson, R.; Cao, J.; Liu, W.X.; Li, B.G.; Shen, W.R.; Zhang, W.J.; Qin, B.; Sun, R.; et al. Residues of hexachlorocyclohexane isomers and their distribution characteristics in soils in the Tianjin area, China. Arch. Environ. Contam. Toxicol. 2004, 46, 432-437.

20. Raina, V.; Suar, M.; Singh, A.; Prakash, O.; Dadhwal, M.; Gupta, S.K.; Dogra, C.; Lawlor, K.; Lal, S.; van der Meer, J.R.; et al. Enhanced biodegradation of hexachlorocyclohexane $(\mathrm{HCH})$ in contaminated soils via inoculation with Sphingobium indicum B90A. Biodegradation 2008, 19, 27-40.

21. Bajpai, A.; Shukla, P.; Dixit, B.S.; Banerji, R. Concentrations of organochlorine insecticides in edible oils from different regions of India. Chemosphere 2007, 67, 1403-1407.

22. Blasco, C.; Lino, C.M.; Pico, Y.; Pena, A.; Font, G.; Silveira, M.I. Determination of organochlorine pesticide residues in honey from the central zone of Portugal and the Valencian community of Spain. J. Chromatogr. 2004, A1049, 155-160.

23. Waliszewski, S.M.; Villalobos-Pietrini, R.; Gomez-Arroyo, S.; Infanzon, R.M. Persistent organochlorine pesticides in Mexican butter. Food Addit. Contam. 2003, 20, 361-367.

24. Sanghi, R.; Pillai, M.K.; Jayalekshmi, T.R.; Nair, A. Organochlorine and organophosphorus pesticide residues in breast milk from Bhopal, Madhya Pradesh, India. Hum. Exp. Toxicol. 2003, $22,73-76$.

25. Zhao, G.; Xu, Y.; Li, W.; Han, G.; Ling, B. PCBs and OCPs in human milk and selected foods from Luqiao and Pingqiao in Zhejiang, China. Sci. Total Environ. 2007, 378, 281-292.

26. Bhatnagar, V.K.; Kashyap, R.; Zaidi, S.S.; Kulkarni, P.K.; Saiyed, H.N. Levels of DDT, HCH, and HCB residues in human blood in Ahmedabad, India. Bull. Environ. Contam. Toxicol. 2004, 72, 261-265.

27. Kutz, F.W.; Wood, P.H.; Bottimore, D.P. Organochlorine pesticides and polychlorinated biphenyls in human adipose tissue. Rev. Environ. Contam. Toxicol. 1991, 120, 1-82.

28. Walker, K.; Vallero, D.A.; Lewis, R.G. Factors influencing the distribution of lindane and other hexachlorocyclohexanes in the environment. Environ. Sci. Technol. 1999, 33, 4373-4378.

29. McGuinness, M.; Dowling, D. Plant-associated bacterial degradation of toxic organic compounds in soil. Int. J. Environ. Res. Public Health 2009, 6, 2226-2247.

30. De Lorenzo, V. Systems biology approaches to bioremediation. Curr. Opin. Biotechnol. 2008, 19, 579-589.

31. De Schrijver, A.; de Mot, R. Degradation of pesticides by actinomycetes. Crit. Rev. Microbiol. 1999, 25, 85-119.

32. Siripattanakul, S.; Wirojanagud, W.; McEvoy, J.; Limpiyakorn, T.; Khan, E. Atrazine degradation by stable mixed cultures enriched from agricultural soil and their characterization. J. Appl. Microbiol. 2009, 106, 986-999. 
33. Yang, C.; Li, Y.; Zhang, K.; Wang, X.; Ma, C.; Tang, H.; Xu, P. Atrazine degradation by a simple consortium of Klebsiella sp. A1 and Comamonas sp. A2 in nitrogen enriched medium. Biodegradation 2010, 21, 97-105.

34. Saez, J.M.; Benimeli, C.S.; Amoroso, M.J. Lindane removal by pure and mixed cultures of immobilized actinobacteria. Chemosphere 2012, 89, 982-987.

35. Böltner, D.; Moreno-Morillas, S.; Ramos, J.L. 16S rDNA phylogeny and distribution of lin genes in novel hexachlorocyclohexane-degrading Sphingomonas strains. Environ. Microbiol. 2005, 7, 1329-1338.

36. Mohn, W.W.; Mertens, B.; Neufeld, J.D.; Verstraete, W.; de Lorenzo, V. Distribution and phylogeny of hexachlorocyclohexane degrading bacteria in soils from Spain. Environ. Microbiol. 2006, 8, 60-68.

37. Phillips, T.M.; Seech, A.G.; Lee, H.; Trevors, J.T. Biodegradation of hexachlorocyclohexane (HCH) by microorganisms. Biodegradation 2005, 16, 363-392.

38. Kidd, P.; Prieto-Fernández, A.; Monterroso, C.; Acea, M.J. Rhizosphere microbial community and hexachlorocyclohexane degradative potential in contrasting plant species. Plant Soil 2008, 302, 233-247.

39. Polti, M.A.; Amoroso, M.J.; Abate, C.M. Chromium (VI) resistance and removal by actinomycete strains isolated from sediments. Chemosphere 2007, 67, 660-667.

40. Siñeriz, M.L.; Kothe, E.; Abate, C.M. Cadmium biosorption by Streptomyces sp. F4 isolated from former uranium mine. J. Basic Microbiol. 2009, 49, 55-62.

41. Benimeli, C.S.; Amoroso, M.J.; Chaile, A.; Castro, G. Isolation of four aquatic streptomycetes strains capable of growth on organochlorine pesticides. Bioresour. Technol. 2003, 89, 133-138.

42. Benimeli, C.S.; Castro, G.R.; Chaile, A.P.; Amoroso, M.J. Lindane removal induction by Streptomyces sp. M7. J. Basic Microbiol. 2006, 46, 348-357.

43. Benimeli, C.S.; Castro, G.; Chaile, A.; Amoroso, M.J. Lindane uptake and degradation by aquatic Streptomyces sp. strain M7. Int. Biodeterior. Biodegrad. 2007, 59, 148-155.

44. Benimeli, C.S.; González, A.J.; Chaile, A.P.; Amoroso, M.J. Temperature and pH effect on lindane removal by Streptomyces sp. M7 in soil extract. J. Basic Microbiol. 2007, 47, 468-473.

45. Benimeli, C.S.; Fuentes, M.S.; Abate, C.M.; Amoroso, M.J. Bioremediation of lindane contaminated soil by Streptomyces sp. M7 and its effects on Zea mays growth. Int. Biodeterior. Biodegrad. 2008, 61, 233-239.

46. Cuozzo, S.A.; Rollán, G.C.; Abate, C.M.; Amoroso, M.J. Specific dechlorinase activity in lindane degradation by Streptomyces sp. M7. World J. Microbiol. Biotechnol. 2009, 25, 1539-1546.

47. Cuozzo, S.A.; Fuentes, M.S.; Bourgignon, N.; Benimeli, C.S.; Amoroso, M.J. Chlordane biodegradation under aerobic conditions by indigenous Streptomyces strains. Int. Biodeterior. Biodegrad. 2012, 66, 19-24.

48. Fuentes, M.S.; Sáez J.M.; Benimeli, C.S.; Amoroso M.J. Lindane biodegradation by defined consortiaof indigenous Streptomyces strains. Water Air Soil Pollut. 2011, 222, 217-231.

49. Bending, G.; Friloux, D.M.; Walker, A. Degradation of contrasting pesticides by White rot fungi and its relationship with ligninolytic potential. FEMS Microbiol. Lett. 2002, 212, 59-63.

50. Jauregui, J.; Valderrama, B.; Albores, A.; Vazquez-Duhalt, R. Microsomal transformation of organophosphorous pesticides by White rot fungi. Biodegradation 2003, 14, 397-406. 
51. Quintero, J.C.; Lú-Chau, T.A.; Moreira, M.T.; Feijoo, G.; Lema, J.M. Bioremediation of HCH present in soil by the white-rot fungus Bjerkandera adusta in a slurry bacth bioreactor. Int. Biodeter. Biodegr. 2007, 60, 319-326.

52. Rubilar, O.; Feijoo, G.; Diez, M.C.; Lu-Chau, T.A.; Moreira, M.T.; Lema, J.M. Biodegradation of pentachlorophenol in soil slurry cultures by Bjerkandera adusta and Anthracophyllum discolor. Indust. Engin. Chem. Res. 2007, 46, 744-751.

53. Van Aken, B.; Correa, P.; Schnoor, J. Phytoremediation of polychlorinated biphenyls: New trends and promises. Environ. Sci. Technol. 2010, 44, 2767-2776.

54. Alvarez, A.; Yañez, M.L.; Benimeli, C.S.; Amoroso, M.J. Maize plants (Zea mays) root exudates enhance lindane removal by native Streptomyces strains. Int. Biodeterior. Biodegrad. 2012, 66, $14-18$.

55. Becerra-Castro, C.; Prieto-Fernández, A.; Kidd, P.S.; Weyens, N.; Rodríguez-Garrido, B.; Touceda-González, M.; Acea, M.J.; Vangronsveld, J. Improving performance of Cytisus striatus on substrates contaminated with hexachlorocyclohexane $(\mathrm{HCH})$ isomers using bacterial inoculants: Developing a phytoremediation strategy. Plant Soil 2012, doi:10.1007/s11104-012-1276-6.

56. Andreu, V.; Picó, Y. Determination of pesticides and their degradation products in soil: Critical review and comparison of methods. Trend. Anal. Chem. 2004, 23, 772-789.

57. Li, S.; Wania, F. Compilation, evaluation, and selection of physical-chemical property data for organochlorine pesticides. J. Chem. Eng. Data 2005, 50, 742-768.

58. Muir, D.C.; Howard, P.H. Are there other persistent organic pollutants? A challenge for environmental chemists. Environ. Sci. Technol. 2006, 40, 7157-7166.

59. Bidleman, T.F. Atmospheric processes. Environ. Sci. Technol. 1988, 22, 361-367.

60. Brubaker, W.W., Jr.; Hites, R.A. Polychlorinated dibenzo-p-dioxins and dibenzofurans: Gas-phase hydroxyl radical reactions and related atmospheric removal. Environ. Sci. Technol. 1997, 31, 1805-1810.

61. Office of Environmental Health Hazard Assessment California Environmental Protection Agency. Public Health Goal for Methoxychlor in Drinking Water; Office of Environmental Health Hazard Assessment California Environmental Protection Agency: Sacramento, CA, USA, 1999.

62. Yule, W.; Chiba, M.; Morley, H. Fate of insecticide residues. Decomposition of lindane in soil. J. Agric. Food Chem., 1967, 15, 1000-1004.

63. Tu, C.M. Utilization and degradation of lindane by soil microorganisms. Arch. Microbiol. 1976, 108, 259-263.

64. Ma, A.Z.; Wu, J.; Zhang, G.S.; Wang, T.; Li, S.P. Isolation and characterization of a HCH degradation Sphingomanas sp. stain BHC-A. Acta Microbiol. Sin. 2005, 45, 728-732.

65. Nalin, R.; Simonet, P.; Vogel, T.M.; Normand, P. Rhodanobacter lindaniclasticus gen. nov., sp. nov., a lindane-degrading bacterium. Int. J. Syst. Bacteriol. 1999, 49, 19-23.

66. Thomas, J.C.; Berger, F.; Jacquier, M.; Bernillon, D.; Baud-Grasset, F.; Truffaut, N.; Normand, P.; Vogel, T.M.; Simonet, P. Isolation and characterization of a novel gamma-hexachlorocyclohexane-degrading bacterium. J. Bacteriol. 1996, 178, 6049-6055.

67. Cérémonie, H.; Boubakri, H.; Mavingui, P.; Simonet, P.; Vogel, T.M. Plasmid-encoded $\gamma$-hexachlorocyclohexane degradation genes and insertion sequences in Sphingobium francense (ex-Sphingomonas paucimobilis $\mathrm{Sp}+$ ). FEMS Microbiol. Lett. 2006, 257, 243-252. 
68. Gupta, A.; Kaushik, C.P.; Kaushik, A. Degradation of hexachlorocyclohexane isomers by two strains of Alcaligenes faecalis isolated from a contaminated site. Bull. Environ. Contam. Toxicol. 2001, 66, 794-800.

69. Datta, J.; Maiti, A.K.; Modak, D.P.; Chakrabartty, P.K.; Bhattacharyya, P.; Ray, P.K. Metabolism of \&-hexachlorocyclohexane by Arthrobacter citreus strain BI-100: Identification of metabolites. J. Gen. App. Microbiol. 2000, 46, 59-67.

70. Lodha, B.; Bhat, P.; Kumar, M.S.; Vaidya, A.N.; Mudliar, S.; Killedar, D.J.; Chakrabarti, T. Bioisomerization kinetics of $\gamma-\mathrm{HCH}$ and biokinetics of Pseudomonas aeruginosa degrading technical HCH. Biochem. Eng. J. 2007, 35, 12-19.

71. Kumar, M.; Chaudhary, P.; Dwivedi, M.; Kumar, R.; Paul, D.; Jain, R.K.; Garg, S.K.; Kumar, A. Enhanced biodegradation of $\beta$ - and $\delta$-hexachlorocyclohexane in the presence of $\alpha$ - and $\gamma$-isomers in contaminated soils. Environ. Sci. Technol. 2005, 39, 4005-4011.

72. Nawab, A.; Aleem, A.; Malik, A. Determination of organochlorine pesticides in agricultural soil with special reference to $\gamma-\mathrm{HCH}$ degradation by Pseudomonas strains. Bioresour. Technol. 2003, $88,41-46$.

73. Dadhwal, M.; Jit, S.; Kumari, H.; Lal, R. Sphingobium chinhatense sp. nov., a hexachlorocyclohexane $(\mathrm{HCH})$-degrading bacterium isolated from an $\mathrm{HCH}$ dumpsite. Int. J. Syst. Evol. Microbiol. 2009, 59, 3140-3144.

74. Sahu, S.K.; Patnaik, K.K.; Sharmila, M.; Sethunathan, N. Degradation of alpha-, beta-, and gamma-hexachlorocyclohexane by a soil bacterium under aerobic conditions. Appl. Environ. Microbiol. 1990, 56, 3620-3622.

75. Bala, K.; Sharma, P.; Lal, R. Sphingobium quisquiliarum sp. nov., a hexachlorocyclohexane $(\mathrm{HCH})$-degrading bacterium isolated from an $\mathrm{HCH}$-contaminated soil. Int. J. Syst. Evol. Microbiol. 2010, 60, 429-433.

76. Singh, A.; Lal, R. Sphingobium ummariense sp. nov., a hexachlorocyclohexane $(\mathrm{HCH})$-degrading bacterium, isolated from HCH-contaminated soil. Int. J. Syst. Evol. Microbiol. 2009, 59, 162-166.

77. Dadhwal, M.; Singh, A.; Prakash, O.; Gupta, S.K.; Kumari, K.; Sharma, P.; Jit, S.; Verma, M.; Holliger, C.; Lal, R. Proposal of biostimulation for hexachlorocyclohexane $(\mathrm{HCH})$-decontamination and characterization of culturable bacterial community from high-dose point HCH-contaminated soils. J. Appl. Microbiol. 2009, 106, 381-392.

78. Manickam, N.; Misra, R.; Mayilraj, S. A novel pathway for the biodegradation of $\gamma$-hexachlorocyclohexane by a Xanthomonas sp. strain ICH12. J. Appl. Microbiol. 2007, 102, 1468-1478.

79. Senoo, K.; Wada, H. Isolation and identification of an aerobic $\gamma$-HCH-decomposing bacterium from soil. Soil Sci. Plant Nutr. 1989, 35, 79-87.

80. Ito, M.; Prokop, Z.; Klvaňa, M.; Otsubo, Y.; Tsuda, M.; Damborský, J.; Nagata, Y. Degradation of $\beta$-hexachlorocyclohexane by haloalkane dehalogenase LinB from $\gamma$-hexachlorocyclohexane-utilizing bacterium Sphingobium sp. MI1205. Arch. Microbiol. 2007, 188, 313-325.

81. Yamamoto, S.; Otsuka, S.; Murakami, Y.; Nishiyama, M.; Senoo, K. Genetic diversity of gamma-hexachlorocyclohexane-degrading sphingomonads isolated from a single experimental field. Lett. Appl. Microbiol. 2009, 49, 472-477. 
82. Francis, A.J.; Spanggord, R.J.; Ouchi, G.I. Degradation of lindane by Escherichia coli. Appl. Microbiol. 1975, 29, 567-568.

83. Benezet, H.J.; Matsumura, F. Isomerization of $\gamma$-BHC to $\alpha$-BHC in the Environment. Nature 1973, 243, 480-481.

84. Lal, R.; Dogra, C.; Malhotra, S.; Sharma, P.; Pal, R. Diversity, distribution and divergence of lin genes in hexachlorocyclohexane-degrading sphingomonads. Trends Biotechnol. 2006, 24, 121-130.

85. Lal, R.; Dadhwal, M.; Kumari, K.; Sharma, P.; Singh, A.; Kumari, H.; Jit, S.; Gupta, S.K.; Nigam, A.; Lal, D.; et al. Pseudomonas sp. to Sphingobium indicum: A journey of microbial degradation and bioremediation of hexachlorocyclohexane. Indian J. Microbiol., 2008, 48, 3-18.

86. Nagata, Y.; Endo, R.; Ito, M.; Ohtsubo, Y.; Tsuda, M. Aerobic degradation of lindane (gamma-hexachlorocyclohexane) in bacteria and its biochemical and molecular basis. Appl. Microbiol. Biotechnol. 2007, 76, 741-752.

87. Nagata, Y.; Miyauchi, K.; Takagi, M. Complete analysis of genes and enzymes for $\gamma$-hexachlorocyclohexane degradation in Sphingomonas paucimobilis UT26. J. Ind. Microbiol. Biotechnol. 1999, 23, 380-390.

88. Wu, J.; Hong, Q.; Han, P.; He, J.; Li, S. A gene linB2 responsible for the conversion of $\mathrm{HCH}$ and 2,3,4,5,6-pentachlorocyclohexanol in Sphingomonas sp. BHC-A. Appl. Microbiol. Biotechnol. 2007, 73, 1097-1105.

89. Imai, R.; Nagata, Y.; Fukuda, M.; Takagi, M.; Yano, K. Molecular cloning of a Pseudomonas paucimobilis gene encoding a 17-kilodalton polypeptide that eliminates $\mathrm{HCl}$ molecules from $\gamma$-hexachlorocyclohexane. J. Bacteriol. 1991, 173, 6811-6819.

90. Nagata, Y.; Nariya, T.; Ohtomo, R.; Fukuda, M.; Yano, K.; Takagi, M. Cloning and sequencing of a dehalogenase gene encoding an enzyme with hydrolase activity involved in the degradation of hexachlorocyclohexane in Pseudomonas paucimobilis. J. Bacteriol. 1993, 175, 6403-6410.

91. Nagata, Y.; Ohtomo, R.; Miyauchi, K.; Fukuda, M.; Yano, K.; Takagi, M. Cloning and sequencing of a 2,5-dichloro-2,5-cyclohexadiene-1,4-diol dehydrogenase gene involved in the degradation of hexachlorocyclohexane in Pseudomonas paucimobilis. J. Bacteriol. 1994, 176, 3117-3125.

92. Miyauchi, K.; Suh, S.K.; Nagata, Y.; Takagi, M. Cloning and sequencing of a 2,5-dichlorohydroquinone reductive dehalogenase gene whose product is involved in degradation of hexachlorocyclohexane by Sphingomonas paucimobilis. J. Bacteriol. 1998, 180, 1354-1359.

93. Endo, R.; Kamakura, M.; Miyauchi, K.; Fukuda, M.; Ohtsubo, Y.; Tsuda, M.; Nagata, Y. Identification and characterization of genes involved in the downstream degradation pathway of $\gamma$-hexachlorocyclohexane in Sphingomonas paucimobilis UT26. J. Bacteriol. 2005, 187, 847-853.

94. Miyauchi, K.; Lee, H.S.; Fukuda, M.; Takagi, M.; Nagata, Y. Cloning and characterization of linR, involved in regulation of the downstream pathway for $\gamma$-hexachlorocyclohexane degradation in Sphingomonas paucimobilis UT26. Appl. Environ. Microbiol. 2002, 68, 1803-1807.

95. Larkin, M.J.; Kulakov, L.A.; Allen C.C. Biodegradation and Rhodococcus-Masters of catabolic versatility. Curr. Opin. Biotechnol. 2005, 16, 282-290.

96. Phillips, T.M.; Seech, A.G.; Lee, H.; Trevors, J.T. Colorimetric assay for lindane dechlorination by bacteria. J. Microbiol. Methods 2001, 47, 181-188. 
97. Andrade, J.M.; Arraiano, C.M. PNPase is a key player in the regulation of small RNAs that control the expression of outer membrane proteins. RNA 2008, 14, 543-551.

98. Normand, P.; Lapierre, P.; Tisa, L.S.; Gogarten, J.P.; Alloisio, N.; Bagnarol, E.; Bassi; C.A., Berry, A.M.; Bickhart, D.M.; Choisne, N.; et al. Genome characteristics of facultatively symbiotic Frankia sp. strains reflect host range and host plant biogeography. Genome Res. 2007, 17, 7-15.

99. Benimeli, C.S. Biodegradation of organochlorine pesticides by aquatic actinomycetes. Ph.D. Thesis, Universidad Nacional de Tucumán, Tucumán, Argentina, 2004.

100. Isaza, J.P.; Duque, C.; Gomez, V.; Robledo, J.; Barrera, L.F.; Alzate, J.F. Whole genome shotgun sequencing of one Colombian clinical isolate of Mycobacterium tuberculosis reveals DosR regulon gene deletions. FEMS Microbiol. Lett. 2012, 330, 113-120.

101. Manickam, N.; Reddy, M.K.; Saini, H.S.; Shanker, R. Isolation of hexachlorocyclohexane-degrading Sphingomonas sp. by dehalogenase assay and characterization of genes involved in $\gamma-\mathrm{HCH}$ degradation. J. Appl. Microbiol. 2008, 104, 952-960.

102. Camacho-Pérez, B.; Ríos-Leal, E.; Esparza-García, F.; Barrera-Cortés, J.; Fava, F.; Poggi-Varaldo, H.M. Bioremediation of an agricultural soil polluted with lindane in triphasic, sequential methanogenic-sulfate reducing slurry bioreactors. J. Biotechnol. 2010, 150, 561-562.

103. Camacho-Pérez, B.; Ríos-Leal, E.; Rinderknecht-Seijas, N.; Poggi-Varaldo, H.M. Enzymes involved in the biodegradation of hexachlorocyclohexane: A mini review. J. Environ. Manag. 2012, 95, S306-S318.

104. Kothe, E.; Dimkpa, C.; Haferburg, G.; Schmidt, A.; Schmidt, A.; Schütze, E. Streptomycete Heavy Metal Resistance: Extracellular and Intracellular Mechanisms. In Soil Heavy Metals; Sherameti, I., Varma, A., Eds.; Springer: Berlin/Heidelberg, Germany, 2010; pp. 225-235.

105. Speedie, M.K.; Pogell, B.M.; MacDonald, M.J.; Kline, R.; Huang, Y.I. Potential usefulness of Streptomyces for the detoxification of recalcitrant organochlorines and other pollutants. Actinomycetes 1987, 20, 315-335.

106. Scherr, N.; Nguyen, L. Mycobacterium versus Streptomyces-We are different, we are the same. Curr. Opin. Microbiol. 2009, 12, 699-707.

107. Shelton, D.R.; Khader, S.; Karns, J.S.; Pogell, B.M. Metabolism of twelve herbicides by Streptomyces. Biodegradation 1996, 7, 129-136.

108. Arisoy, M.; Kolankaya, N. Biodegradation of lindane by Pleurotus sajor-caju and toxic effects of lindane and its metabolites on mice. Bull. Environ. Contam. Toxicol. 1997, 59, 352-359.

109. Bachmann, A.; Wijnen, P.; DeBruin, W.; Huntjens, J.L.M.; Roelofsen, W.; Zehnder, A.J.B. Biodegradation of alpha- and beta-hexachlorocyclohexane in a soil slurry and under different redox conditions. Appl. Environ. Microbiol. 1988, 54, 143-149.

110. Manonmani, H.K.; Chandrashekariah, D.H.; Sreedhar Reddy, N.; Elecy, C.D.; Kunhi, A.A.M. Isolation and acclimation of a microbial consortium for improved aerobic degradation of $\alpha$-hexachlorocyclohexane. J. Agric. Food Chem. 2000, 48, 4341-4351.

111. Siddique, T.; Okeke, B.C.; Arshad, M.; Frankerberger, W.T., Jr. Temperature and pH effects on biodegradation of hexachlorocyclohexane isomers in water and soil slurry. J. Agric. Food Chem. 2002, 50, 5070-5076. 
112. Zheng, G.; Selvam, A.; Wong, J.W.C. Rapid degradation of lindane ( $\gamma$-hexachlorocyclohexane) at low temperature by Sphingobium strains. Int. Biodeterior. Biodegrad. 2011, 65, 612-618.

113. Antizar-Ladislao, B. Bioremediation-Bacterial Alchemists. Elements 2010, 6, 389-394.

114. Rodriguez, R.A.; Toranzos, G.A. Stability of bacterial populations in tropical soil upon exposure to Lindane. Int. Microbiol. 2003, 6, 253-258.

115. Gerhardt, K.E.; Huang, X.D.; Glick, B.R.; Greenberg, B.M. Phytoremediation and rhizoremediation of organic soil contaminants: Potential and challenges. Plant Sci. 2009, 176, 20-30.

116. Kuiper, I.; Lagendijk, E.L.; Bloemberg, G.V.; Lugtenberg, B.J. Rhizoremediation: A beneficial plant-microbe interaction. Mol. Plant Microbe Interact. 2004, 17, 6-15.

117. Gao, Y.; Ren, L.; Ling, W.; Gong, S.; Sun, B.; Zhang, Y. Desorption of phenanthrene and pyrene in soils by root exudates. Bioresour. Technol. 2010, 101, 1159-1165.

118. Barriada-Pereira, M.; Gonzalez-Castro, M.J.; Muniategui-Lorenzo, S.; López-Mahía, P.; Prada-Rodríguez, D.; Fernández-Fernández, E. Organochlorine pesticides accumulation and degradation products in vegetation samples of a contaminated area in Galicia (NW Spain). Chemosphere 2005, 58, 1571-1578.

119. Magee, K.; Michael, A.; Ulla, H.; Dutta, S.K. Dechlorination of PCB in the presence of plant nitrate reductase. Environ. Toxicol. Pharm. 2008, 25, 144-147.

120. Huang, X.D.; El-Alawi, Y.; Penrose, D.M.; Glick, B.R.; Greenberg, B.M. Responses of three grass species to creosote during phytoremediation. Environ. Pollut. 2004, 130, 453-463.

121. Weyens, N.; Truyens, S.; Dupae, J.; Newman, L.; Taghavi, S.; van der Lelie, D.; Carleer, R.; Vangronsveld, J. Potential of the TCE-degrading endophyte Pseudomonas putida W619-TCE to improve plant growth and reduce TCE phytotoxicity and evapotranspiration in poplar cuttings. Environ. Pollut. 2010, 158, 2915-2919.

122. Lin, Q.; Shen, K.L.; Zhao, H.M.; Li, W.H. Growth response of Zea mays L. in pyrene-copper co-contaminated soil and the fate of pollutants. J. Hazard. Mater. 2008, 150, 515-521.

123. Pereira, C.R.; Camps-Arbestain, M.; Garrido, B.R.; Macías, F.; Monterroso, C. Behaviour of $\alpha-$, $\beta$-, $\gamma$-, and $\delta$-hexachlorocyclohexane in the soil-Plant system of a contaminated site. Environ. Pollut. 2006, 144, 210-217.

124. Germaine, K.J.; Keogh, E.; Ryan, D.; Dowling, D.N. Bacterial endophyte-mediated naphthalene phytoprotection and phytoremediation. FEMS Microbiol. Lett. 2009, 296, 226-234.

125. Rentz, J.; Alvarez, P.; Schnoor, J. Repression of Pseudomonas putida phenanthrene-degrading activity by plant root extracts and exudates. Environ. Microbiol. 2004, 6, 574-583.

126. Louvel, B.; Cébron, A.; Leyval, C. Root exudates affect phenanthrene biodegradation, bacterial community and functional gene expression in sand microcosms. Int. Biodeter. Biodegr. 2011, 65, 947-953.

127. Sáinz, M.J.; González-Penalta, B.; Vilariño, A. Effects of hexachlorocyclohexane on rhizosphere fungal propopagules and root colonization by arbuscular mycorrhizal fungi in Plantago lanceolata. Eur. J. Soil Sci. 2006, 57, 83-90.

(C) 2012 by the authors; licensee MDPI, Basel, Switzerland. This article is an open access article distributed under the terms and conditions of the Creative Commons Attribution license (http://creativecommons.org/licenses/by/3.0/). 